\title{
Assessing liner performance using on-farm milk meters
}

\author{
J. F. Penry, ${ }^{\star 1}$ S. Leonardi,† J. Upton,ł P. D. Thompson,§ and D. J. Reinemann§ \\ *Department of Dairy Science, University of Wisconsin-Madison, Madison 53706 \\ †Department of Health, Animal Science and Food Safety, Universita degli Studi di Milano, 20133 Milan, Italy \\ $\ddagger$ Animal and Grassland Research and Innovation Centre, Teagasc Moorepark Fermoy, Co. Cork, Ireland \\ $\S$ Department of Biological Systems Engineering, University of Wisconsin-Madison, Madison 53706
}

\begin{abstract}
The primary objective of this study was to quantify and compare the interactive effects of liner compression, milking vacuum level, and pulsation settings on average milk flow rates for liners representing the range of liner compression of commercial liners. A secondary objective was to evaluate a methodology for assessing liner performance that can be applied on commercial dairy farms. Eight different liner types were assessed using 9 different combinations of milking system vacuum and pulsation settings applied to a herd of 80 cows with vacuum and pulsation conditions changed daily for $36 \mathrm{~d}$ using a central composite experimental design. Liner response surfaces were created for explanatory variables milking system vacuum $\left(\mathrm{V}_{\text {system }}\right)$ and pulsator ratio (PR) and response variable average milk flow rate $(\mathrm{AMF}=$ total yield/total cups-on time $)$ expressed as a fraction of the within-cow average flow rate for all treatments (average milk flow rate fraction, $\mathrm{AMF}_{\mathrm{f}}$ ). Response surfaces were also created for between-liner comparisons for standardized conditions of claw vacuum and milk ratio (fraction of pulsation cycle during which milk is flowing). The highest $\mathrm{AMF}_{\mathrm{f}}$ was observed at the highest levels of $\mathrm{V}_{\text {system }}, \mathrm{PR}$, and overpressure. All liners showed an increase in AMF as milking conditions were changed from low to high standardized conditions of claw vacuum and milk ratio. Differences in AMF between liners were smallest at the most gentle milking conditions (low $\mathrm{V}_{\text {system }}$ and low milk ratio), and these between-liner differences in AMF increased as liner overpressure increased. Differences were noted with vacuum drop between $V_{\text {system }}$ and claw vacuum depending on the liner venting system, with short milk tube vented liners having the greater vacuum drop than mouthpiece chamber vented liners. The accuracy of liner performance assessment in com-
\end{abstract}

Received August 25, 2015.

Accepted April 15, 2016.

${ }^{1}$ Corresponding author: penry@wisc.edu mercial parlors fitted with milk meters can be improved by using a central composite experimental design with a repeated center point treatment, rotating different clusters to different stalls (milk meters), and adjusting performance estimates for similar claw vacuum and pulsation conditions.

Key words: liner performance, milking speed, average milk flow rate, milking vacuum, pulsation settings

\section{INTRODUCTION}

The general aims of milk harvesting are to milk with comfort and speed while not compromising mechanisms of teat defense against mastitis pathogen invasion. Dairy farmers have a large selection of liners to choose from to achieve these goals, with design features including several types of material; round, triangular, oval, and square shapes; vents in the short milk tube (SMT) or mouthpiece chamber (MPC); and other features.

Numerous studies have demonstrated that for a given liner type, milking speed will increase with increasing milking system vacuum ( $\left.\mathbf{V}_{\text {system }}\right)$ (Clough, 1972; Thomas et al., 1993b; Rasmussen and Madsen, 2000; Spencer and Rogers, 2004; Spencer et al., 2007). However, it is also understood that vacuum causes congestion by drawing circulating blood and extracellular fluid into the arterioles, venules, and surrounding tissue within the teat apex as it expands under the influence of vacuum. Liner compression (LC), applied primarily during the d-phase of pulsation, provides an opposing force on the teat end to counter the formation of congestion. Mein et al. (1987) postulated that a compressive load (alternate term for LC) of about 12 $\mathrm{kPa}$, applied for a sufficient period, would be adequate to relieve congestion and that any additional increase in compression supplied by the collapsed liner would provide little benefit. Mein et al. (2003) presented an explanation based on physical and physiological principles that LC is a function of both liner design and the pressure difference across the liner during the $d$ phase, and that the LC required to relieve teat congestion increases as $\mathrm{V}_{\text {system }}$ increases. Bade et al. (2007) 
subsequently showed that LC is positively correlated with the pressure difference across the liner. Williams et al. (1981) demonstrated that increased LC resulted in increased peak milk flow rate, and Mein et al. (2003) reported that increasing LC also raises the risk of hyperkeratosis and that postmilking teat canal openness could be caused by high vacuum levels, high LC, and long milking duration. Zucali et al. (2008) also found that increased LC was associated with the development of hyperkeratosis. Understanding the role of $\mathrm{LC}$ is thus clearly important for predicting the balance between milking gentleness and speed. Gomez et al. (2011) used the overpressure (OP) method described by Mein et al. (2003) as a biologically relevant indicator of relative LC and found a 6 -fold range in OP across 26 commercial liners.

Pulsation characteristics also influence milking speed and gentleness. Milk flow rate change with altered pulsation settings can be partially explained by the fraction of time during each pulsation cycle that milk is flowing. Congestion of teat end tissues can also have an effect on milk flow rates. Peak milk flow rate has been shown to increase with increasing b-phase duration (Clough, 1972; Spencer et al., 2007). Increasing either b-phase duration or teat end vacuum was shown to result in increased teat-end thickness after milking (Hamann et al., 1993), and Williams et al. (1981) showed that increasing the $\mathrm{b}$ phase from 500 to $1,500 \mathrm{~ms}$ resulted in increased teat end congestion. Thomas et al. (1993a) demonstrated that increasing pulsator ratio (PR) from 50:50 to 70:30 with a constant pulsation rate (60 pulsations per minute) reduced milking time by about $25 \%$ with a $\mathrm{V}_{\text {system }}$ level of $42 \mathrm{kPa}$ and reduced total milking time by only $5 \%$ with a $\mathrm{V}_{\text {system }}$ level of $51 \mathrm{kPa}$. This reduced effect of pulsation ratio at high vacuum level is an indication of increased teat tissue congestion occurring at high vacuum levels. International Organisation for Standardization (ISO) 5707 (ISO, 2007b) specifies that the d-phase of pulsation should be greater than $150 \mathrm{~ms}$.

Hillerton (2005) claimed that although several efforts had been made to model liner performance, liner design had largely been driven by commercial influences. Schukken et al. (2006) stated that no formal guidelines on assessing liner performance exist. ISO 3918 (ISO, 2007a), identifies several physical characteristics of liners of potential interest including diameter of the mouthpiece lip, inner diameter at midbarrel, mouthpiece depth, and liner effective length. Touch point pressure difference (TPPD) is mentioned as a physical characteristic of a liner, but no guidance is given as to the appropriate value. Reinemann et al. (2013) demonstrated that the correlation between TPPD and OP was weak for round liners and that TPPD cannot be used to estimate the OP of triangular or square liners.

In concept, the steps required to create ideal machine milking conditions appear simple. First, it is generally accepted that farmers and advisers should select a liner that is a good fit to the majority of teat dimensions in the herd. Then vacuum and pulsation settings can be chosen to achieve a balance between the competing aims of reasonable milking speed and gentleness of milking. The common reality is that these decisions are often made on a trial and error basis for any given liner type. A more repeatable and objective approach to assessing liner performance under a range of vacuum and pulsation settings would benefit the dairy industry.

The primary objective of this study was to quantify and compare the interactive effects of liner compression, milking vacuum level, and pulsation settings on average milk flow rates for liners representing the range of liner compression of commercial liners. A secondary objective was to evaluate a methodology for assessing liner performance that can be applied on commercial dairy farms.

\section{MATERIALS AND METHODS}

\section{Milking Facilities}

The experiment was carried out at the University of Wisconsin-Madison Dairy Cattle Center in a double-6 herringbone milking parlor incorporating a low-level milk line. The experiment used 80 Holstein cows milked twice a day at 12-h intervals for $36 \mathrm{~d}$. Each milking was performed with the normal parlor routine (forestrip, predip, and drying, attachment $90 \mathrm{~s}$ after forestrip). Characteristics of the cows at the start of the experiment were as follows: parity range from 1 to 4; DIM range from 54 to 308 ; average daily milk yield $36.8 \pm$ $9.9 \mathrm{~kg} / \mathrm{cow}$. Parlor milking unit detachers were set with a takeoff threshold of $0.6 \mathrm{~kg} / \mathrm{min}$ and a delay of $5 \mathrm{~s}$. Parlor milk meters supplied milk flow rate information to the detachers (Boumatic Perfection Meter, Madison, WI).

\section{Experimental Design}

The characteristics of the 8 liners tested are summarized in Table 1. Chosen liners were commercial, experimental, or prototype models. The OP for each liner was measured according to the method described in Leonardi et al. (2015). Liners A, D, E, and F were used in 2 stalls each during the course of the experiment. Liners $\mathrm{B}, \mathrm{Bv}, \mathrm{C}$, and $\mathrm{Cv}$ were used in one stall each because $\mathrm{B}$ and $\mathrm{Bv}$ had the same geometry and liner 
properties with the exception of the venting system. The scenario for liners $\mathrm{C}$ and $\mathrm{Cv}$ was the same.

A 2-variable inscribed central composite design (CCD) was used as the experimental design. This procedure is a useful method for producing response surfaces relating 2 explanatory variables to a third response variable (Box and Wilson, 1951). The explanatory variables in our study were milking $\mathrm{V}_{\text {system }}$ and PR, with average milk flow rate as the response variable. The design consists of a center point $(\mathbf{C P t})$ with 4 axial and 4 factorial treatment points (Figure $1)$. The $\mathrm{CPt}$ is crucial to the CCD because it assists in controlling for variance as each treatment point is applied. The axial points represent the extreme values (high and low) of the explanatory variables, which in this case were extreme values of $\mathrm{V}_{\text {system }}$ and $\mathrm{PR}$ seen in commercial parlors. Each treatment point, including the $\mathrm{CPt}$, represented a specific combination of $\mathrm{V}_{\text {system }}$ and PR. The factorial points are brought into the interior of the design space (inscribed) so that all points are equal "distance" from the CPt. Theoretically, milk flow rate from the teat canal is proportional to PR and to the square root of $\mathrm{V}_{\text {system }}$ (Reinemann and Mein, 2010), and treatment levels were chose to represent the range of $P R$ and $V_{\text {system }}$ settings potentially seen in commercial parlors. The CCD provides equal leverage across treatment points. Axial and factorial points were randomly assigned an order of application with the $\mathrm{CPt}$ repeated after every third treatment for the first 12-d block, applied again in reverse order during the second 12-d block, and applied again in the original order for a final 12-d block. Assignment of milking stall to each cow at each milking was random according to the order in which cows entered the parlor.

Average milk flow rate per cow (AMF; total yield in kilograms divided by total cups-on time in minutes) was measured with a commercial milk meter at each stall. On the first day of the experiment SMT vacuum, claw vacuum $\left(\mathbf{V}_{\text {claw }}\right)$, and MPC vacuum were recorded using the VaDia vacuum recorder (BioControl, Rakkestad, Norway) for 4 cow-milkings for each of the liner types. The treatment applied on this day was the CPt. These measurements were used to predict the relationship between $\mathrm{V}_{\text {system }}$ and $\mathrm{V}_{\text {claw }}$ for varying milk flow rates for each cluster configuration (Bade et al., 2009). Average $\mathrm{V}_{\text {claw }}$ during the second minute of attachment (from VaDia recordings) was regressed against milk flow rate measured during the second minute of unit attachment (from milk meter recordings).

$\mathrm{PR}$ and pulsation rate were adjusted to approximate a d-phase of about $295 \mathrm{~ms}$ for all treatments. Milking $\mathrm{V}_{\text {system }}$ and pulsation settings were changed every day before the evening milking. Pulsation phase durations were then confirmed with a dry test of pulsation and found to change across liner type and $\mathrm{V}_{\text {system }}$. This $\mathrm{d}-$ phase duration is greater than the ISO recommendation of $150 \mathrm{~ms}$, and it was chosen to ensure sufficient rest phase duration to relieve teat end congestion for all treatments. It was also the lower limit of d-phase duration allowed within the parlor pulsation control system, while still allowing for all CCD PR settings with a single d-phase duration. Liner OP values were used to estimate MR for each treatment. Liners were shifted clockwise one parlor stall every $2 \mathrm{~d}$ to control for variability in milk meter calibrations.

\section{Data Analysis}

Cows that did not participate in at least 2 out of the 3 experimental cycles were dropped from the analysis. Records indicating that the cluster had been manually reattached during milking or manually detached at the end of milking were removed from the analysis, as were all milkings of cows that received mastitis treatment ( $15.5 \%$ of the data). Average milk flow rate data were assessed using a quantile-quantile plot and found to be normally distributed. The average of AMF across all treatments was calculated for each cow. Individual

Table 1. Selected liner characteristics

\begin{tabular}{|c|c|c|c|c|c|c|c|c|}
\hline Liner & Material $^{1}$ & Shape $^{2}$ & $\begin{array}{l}\mathrm{MP}^{3} \text { depth } \\
\quad(\mathrm{mm})\end{array}$ & $\begin{array}{l}\text { MP diameter } \\
(\mathrm{mm})\end{array}$ & $\begin{array}{c}\text { Mid-barrel } \\
\text { diameter }(\mathrm{mm})\end{array}$ & $\begin{array}{l}\text { Wall thickness } \\
\qquad(\mathrm{mm})\end{array}$ & Venting $^{4}$ & $\begin{array}{l}\mathrm{OP}^{5} \\
(\mathrm{kPa})\end{array}$ \\
\hline A & NR & $\mathrm{R}$ & 34 & 22.0 & 21.0 & 2.1 & None & 18.2 \\
\hline D & NR & $\mathrm{T}$ & 29 & 21.0 & 21.0 & 1.8 & None & 10.5 \\
\hline $\mathrm{E}$ & NR & $\mathrm{T}$ & 35 & 21.0 & 21.0 & 2.0 & MPC & 9.8 \\
\hline $\mathrm{F}$ & $\mathrm{S}$ & $\mathrm{T}$ & 38 & 21.0 & 24.0 & 2.0 & SMT & 0.0 \\
\hline
\end{tabular}

${ }^{1} \mathrm{NR}=$ nitrile rubber; $\mathrm{S}=$ silicon.

${ }^{2} \mathrm{R}=$ round; $\mathrm{T}=$ triangular.

${ }^{3} \mathrm{MP}=$ mouthpiece; MP depth measured with $40 \mathrm{kPa}$ applied to short milk tube.

${ }^{4} \mathrm{SMT}=$ venting in short milk tube; $\mathrm{MPC}=$ venting in mouthpiece chamber.

${ }^{5} \mathrm{OP}=$ overpressure (limited pulsation). 


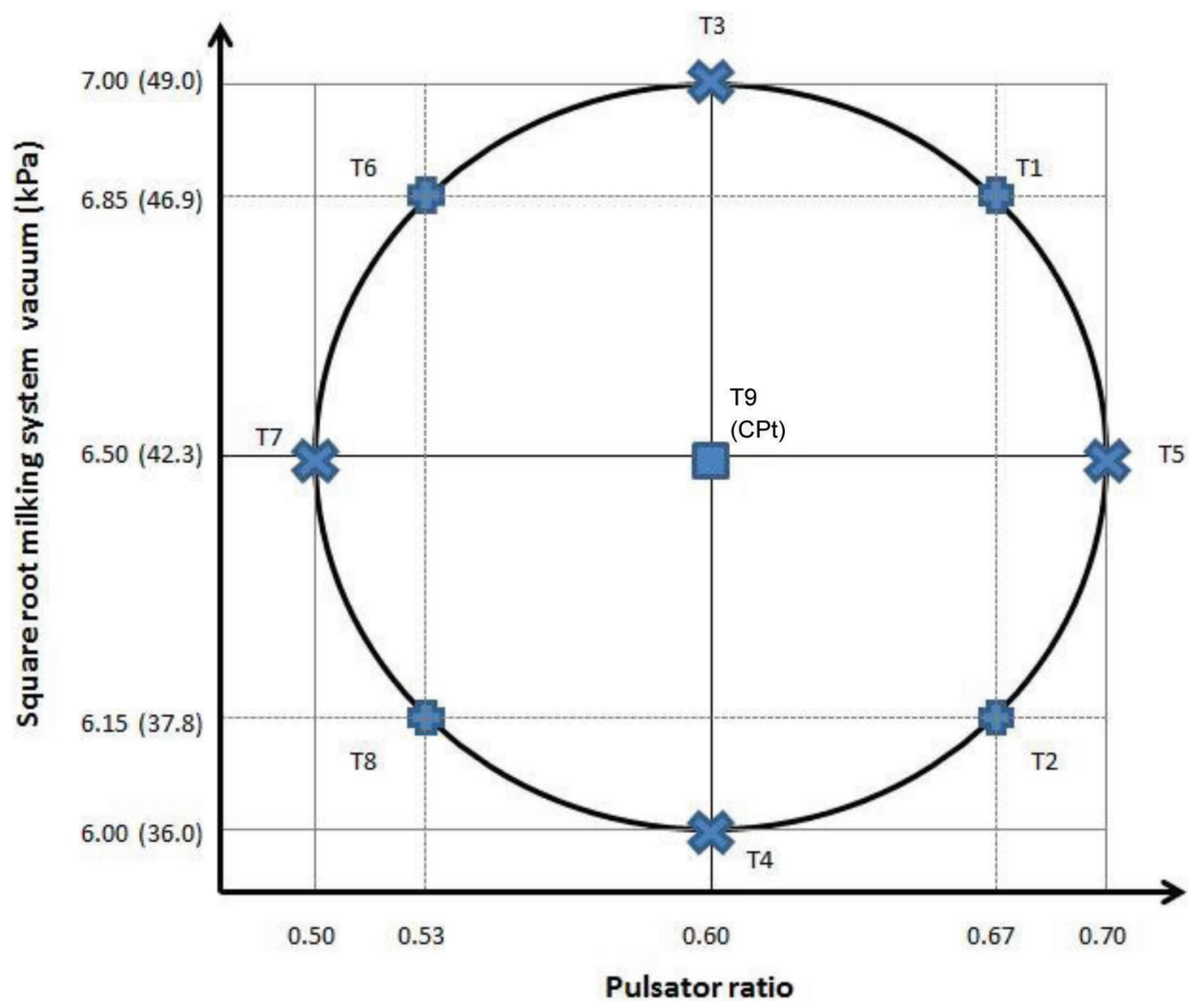

Figure 1. Nine treatments $(\mathrm{T})$ for 2 explanatory variable inscribed central composite design $(\mathrm{CCD})$. CPt $=$ center point. Color version available online.

milking AMF was then divided by this within-cow average AMF to calculate the average milk flow rate fraction $\left(\mathbf{A M F}_{\mathrm{f}}\right)$ for each cow for each milking session.

A mixed model (PROC MIXED, SAS 9.4, SAS Institute Inc., Cary, NC, 2009) for $\mathrm{AMF}_{\mathrm{f}}$ assessed the effects of treatment ( $\mathrm{CPt}$ and $\mathrm{T} 1-\mathrm{T} 8)$ and liner type along with covariates (stall number, operator, time of day of milking [morning or evening], experimental cycle, teat length) with all explanatory variables entered as class variables where appropriate. Cow was declared as both a random and a repeated effect. The effects of time of day, teat length group, and experimental cycle were not significant and were removed from the model $(P$-value of $>0.05)$.

The final model was $\mathrm{AMF}_{\mathrm{f}}=$ treatment + liner type + stall + operator + (liner type $\times$ treatment $)$. The least squares means (LSM) for $\mathrm{AMF}_{\mathrm{f}}$ were computed for each treatment and liner type combination in the model. The LSM values were used to generate a 3-dimensional response surface for each liner by solving for coefficients $\mathrm{C}_{0}$ to $\mathrm{C}_{5}$ using a multiple regression for the following quadratic model with first-order interaction:

$$
\begin{aligned}
\mathrm{AMF}_{\mathrm{f}} & =\mathrm{C}_{0}+\mathrm{C}_{1} \mathrm{~V}_{\text {system }}+\mathrm{C}_{2} \mathrm{~V}_{\text {system }}{ }^{2}+\mathrm{C}_{3} \mathrm{PR} \\
& +\mathrm{C}_{4} \mathrm{PR}^{2}+\mathrm{C}_{5} \mathrm{~V}_{\text {system }} \times \mathrm{PR} .
\end{aligned}
$$

These predictors were chosen as those most applicable for parlor operators when choosing $V_{\text {system }}$ levels and pulsation settings for a specific liner installed on a specific milking machine.

Milk flow rate is most directly affected by $\mathrm{V}_{\text {claw }}$ as well as the milk ratio (MR), or fraction of the total pulsation cycle during which milk is flowing. Although $\mathrm{V}_{\text {system }}$ and $\mathrm{PR}$ were the same for all liners for each treatment condition, $\mathrm{V}_{\text {claw }}$ and $\mathrm{MR}$ differed between liners and treatment conditions because of differences in venting, pulsation chamber volume, and liner OP. These effects were accounted for so that comparisons could be made between liners under the same $V_{\text {claw }}$ and MR conditions; MR was estimated from dry tests of pulsation by calculating the fraction of the pulsation cycle that pulsation chamber vacuum was greater than $\mathrm{OP}$ for each liner under each treatment condition; $\mathrm{V}_{\text {claw }}$ 
was estimated using the relationship developed from the VaDia milking-time tests described previously. A mixed model approach was used to develop the following final model: $\mathrm{AMF}=$ treatment + liner type + stall + operator + (liner type $\times$ treatment). The LSM for $\mathrm{AMF}$ were used to generate a 3-dimensional response surface for each liner by solving for coefficients $\mathrm{C}_{0}$ to $\mathrm{C}_{5}$ by using a multiple regression for the following quadratic model with first-order interaction:

$$
\begin{aligned}
\mathrm{AMF} & =\mathrm{C}_{0}+\mathrm{C}_{1} \mathrm{~V}_{\text {claw }}+\mathrm{C}_{2} \mathrm{~V}_{\text {claw }}{ }^{2}+\mathrm{C}_{3} \mathrm{MR}+\mathrm{C}_{4} \mathrm{MR}^{2} \\
& +\mathrm{C}_{5} \mathrm{~V}_{\text {claw }} \times \mathrm{MR} .
\end{aligned}
$$

From the response surfaces, predicted AMF for each liner was derived for the following 3 standard conditions for combinations of $\mathrm{V}_{\text {claw }}$ and $\mathrm{MR}$ representative of the low, medium, and high levels of milking aggressiveness as follows:

$$
\begin{gathered}
\text { Low: } \mathrm{V}_{\text {claw }}=32 \mathrm{kPa}, \mathrm{MR}=0.5, \\
\text { Medium: } \mathrm{V}_{\text {claw }}=37 \mathrm{kPa}, \mathrm{MR}=0.6, \\
\text { High: } \mathrm{V}_{\text {claw }}=42 \mathrm{kPa}, \mathrm{MR}=0.7 .
\end{gathered}
$$

\section{RESULTS}

The results for the final $\mathrm{AMF}_{\mathrm{f}}$ mixed model are presented in Table 2, treatment LS means for each liner type in Table 3, and response surface coefficients in Table 4. Note that an $\mathrm{AMF}_{\mathrm{f}}$ value of 1.0 is the within-
Table 2. Results for mixed model: AMF fraction $=$ stall + operator + treatment + liner type $+($ treatment $\times$ liner type $)$

\begin{tabular}{lrrr}
\hline Effect & df & F value & $P$-value \\
\hline Stall & 11 & 2.57 & 0.0030 \\
Operator & 5 & 5.13 & 0.0001 \\
Treatment & 8 & 162.34 & $<0.0001$ \\
Liner type & 7 & 85.01 & $<0.0001$ \\
Treatment $\times$ liner type & 56 & 1.81 & 0.0002 \\
\hline
\end{tabular}

cow average across all treatments and not the average of the $\mathrm{CPt}$ treatment values. Example $\mathrm{AMF}_{\mathrm{f}}$ response surfaces for liners with the maximum OP (liner A) and minimum $\mathrm{OP}$ (liner $\mathrm{F}$ ) are presented in Figures 2 and 3 , respectively.

The value for $\mathrm{AMF}_{\mathrm{f}}$ increased continuously for liners $\mathrm{A}$ and $\mathrm{F}$ with both increasing $\mathrm{V}_{\text {system }}$ and $\mathrm{PR}$, although the rate of change, as indicated by the slope of the response surface, was different for the highest OP liner (A) compared with that for the lowest OP liner $(\mathrm{F})$. For high OP liner $\mathrm{A}, \mathrm{AMF}_{\mathrm{f}}$ ranged from 0.85 to 1.26. The corresponding range in $\mathrm{AMF}_{\mathrm{f}}$ for low $\mathrm{OP}$ liner $\mathrm{F}$ was smaller, from 0.77 to 1.09. Differences in OP were most apparent at combinations of high $\mathrm{V}_{\text {system }}$ and $\mathrm{PR}$. For the majority of the liners, the maximum $\mathrm{AMF}_{\mathrm{f}}$ occurred at the highest $\mathrm{V}_{\text {system }}$ and $\mathrm{PR}$, but liners $\mathrm{B}$ and $\mathrm{Bv}$ were exceptions.

Regression results for $\mathrm{V}_{\text {claw }}$ versus milk flow rate for different venting configurations are presented in Table 5. The vacuum drop between $\mathrm{V}_{\text {system }}$ and $\mathrm{V}_{\text {claw }}$ was highest for SMT vented liners, followed by the MPC vented liner, and lowest for the unvented liners.

Table 3. Mixed model solution for within-liner AMF fraction of average of all treatments least squares means ${ }^{1}$

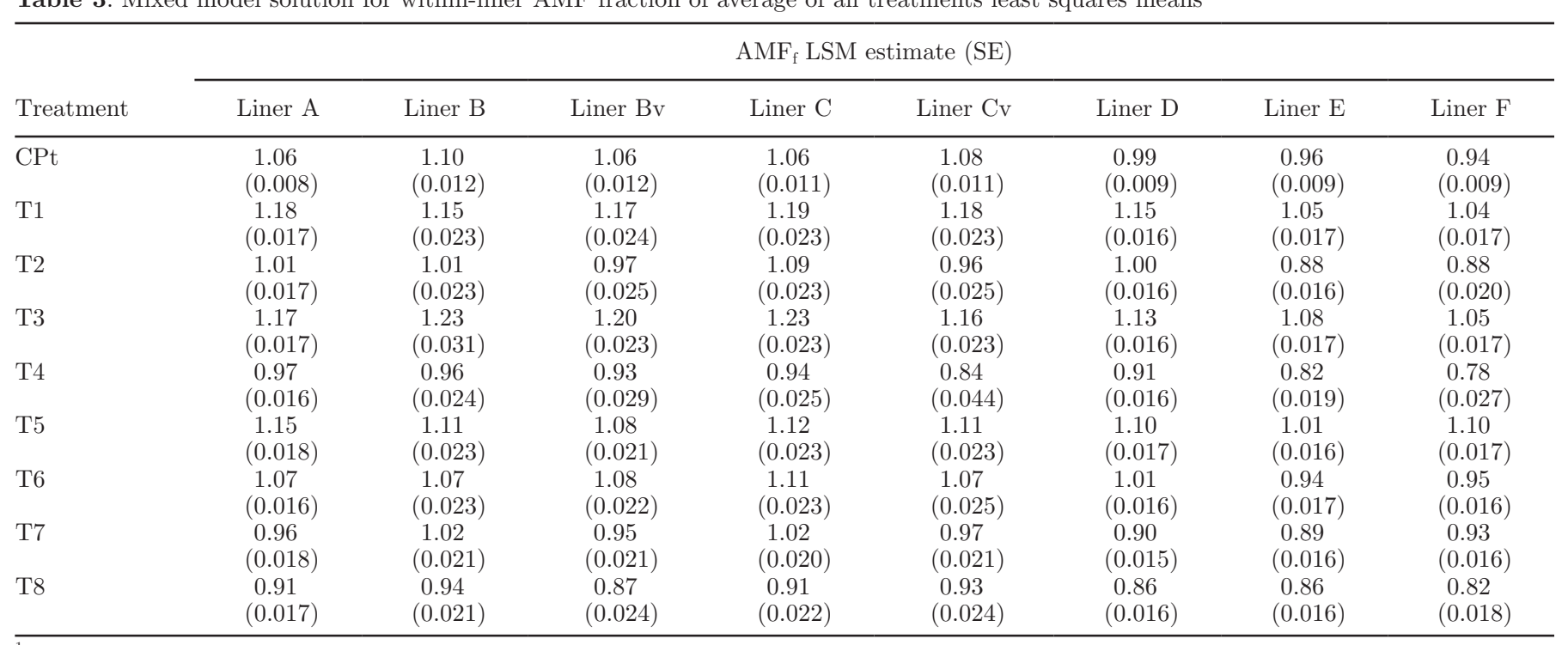

${ }^{1} \mathrm{AMF}_{\mathrm{f}} \mathrm{LSM}$ estimate: LSM estimate for average milk flow (AMF) fraction being a fraction of the within-cow average AMF for all treatments within liner. The standard error is presented in parentheses. $\mathrm{CPt}=$ center point. 
Table 4. Average milk flow fraction response surface coefficients ${ }^{1}$

\begin{tabular}{|c|c|c|c|c|c|c|c|c|}
\hline Liner & A & B & $\mathrm{Bv}$ & $\mathrm{C}$ & $\mathrm{Cv}$ & D & $\mathrm{E}$ & $\mathrm{F}$ \\
\hline
\end{tabular}

${ }^{1} \mathrm{~V}_{\text {system }}=$ system vacuum; $\mathrm{V}_{\text {system }}{ }^{2}=$ system vacuum squared; $\mathrm{PR}=$ pulsator ratio; $\mathrm{PR}^{2}=$ pulsator ratio squared; $\mathrm{V}_{\text {system }} \times \mathrm{PR}=$ interactive term of system vacuum and pulsator ratio.

The AMF response surface coefficients for all liners are presented in Table 6 , and AMF values for the 3 standardized conditions of $\mathrm{V}_{\text {claw }}$ and $\mathrm{MR}$ are presented in Figure 4. All liners showed an increase in AMF as standard conditions progressed from low to high milking aggressiveness. The lowest OP liner (F) had the

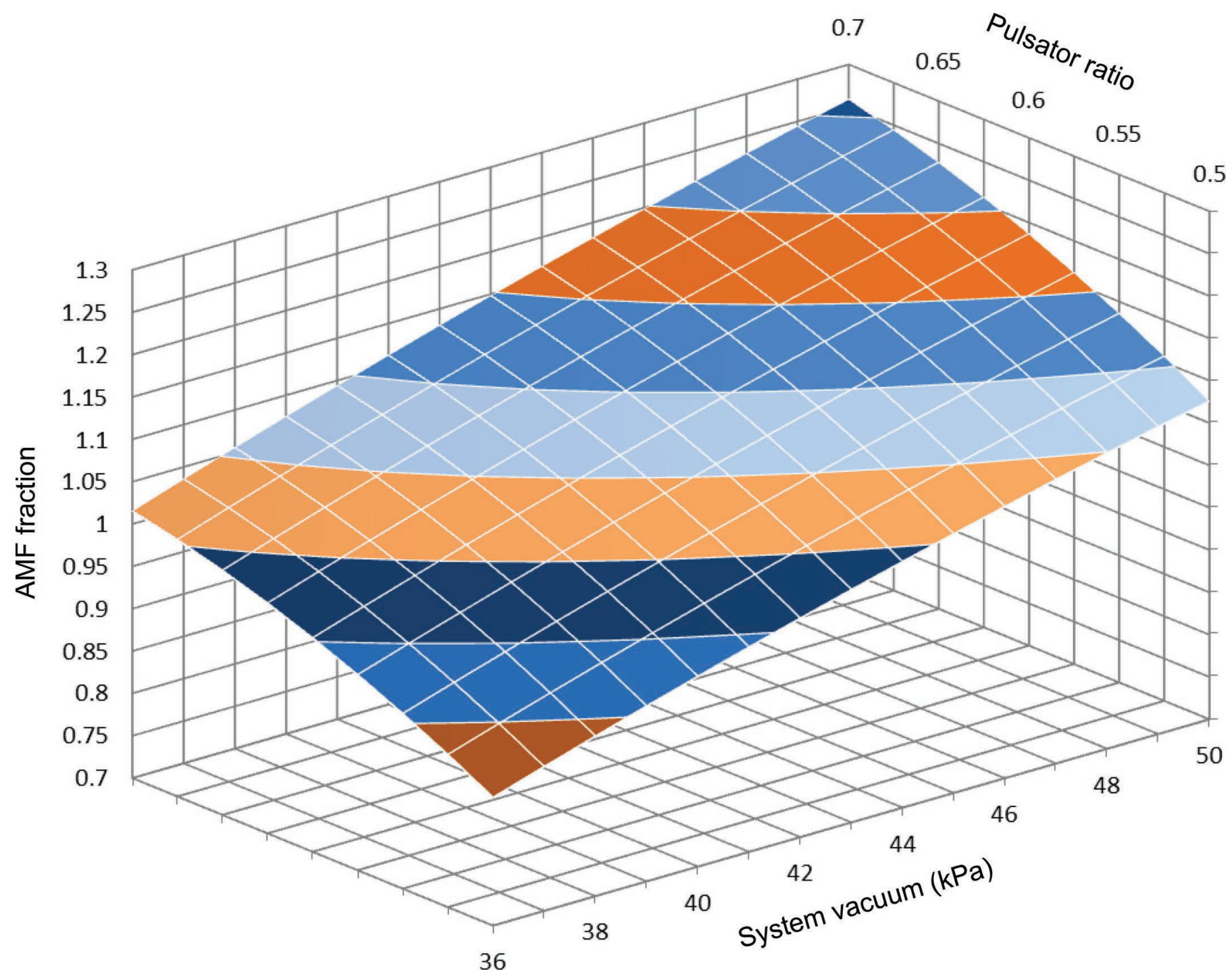

Figure 2. Average milk flow fraction response surface - Liner A. Average milk flow (AMF) is defined as a fraction around the average AMF relative to the within-cow mean for all treatments by system vacuum and pulsator ratio. 


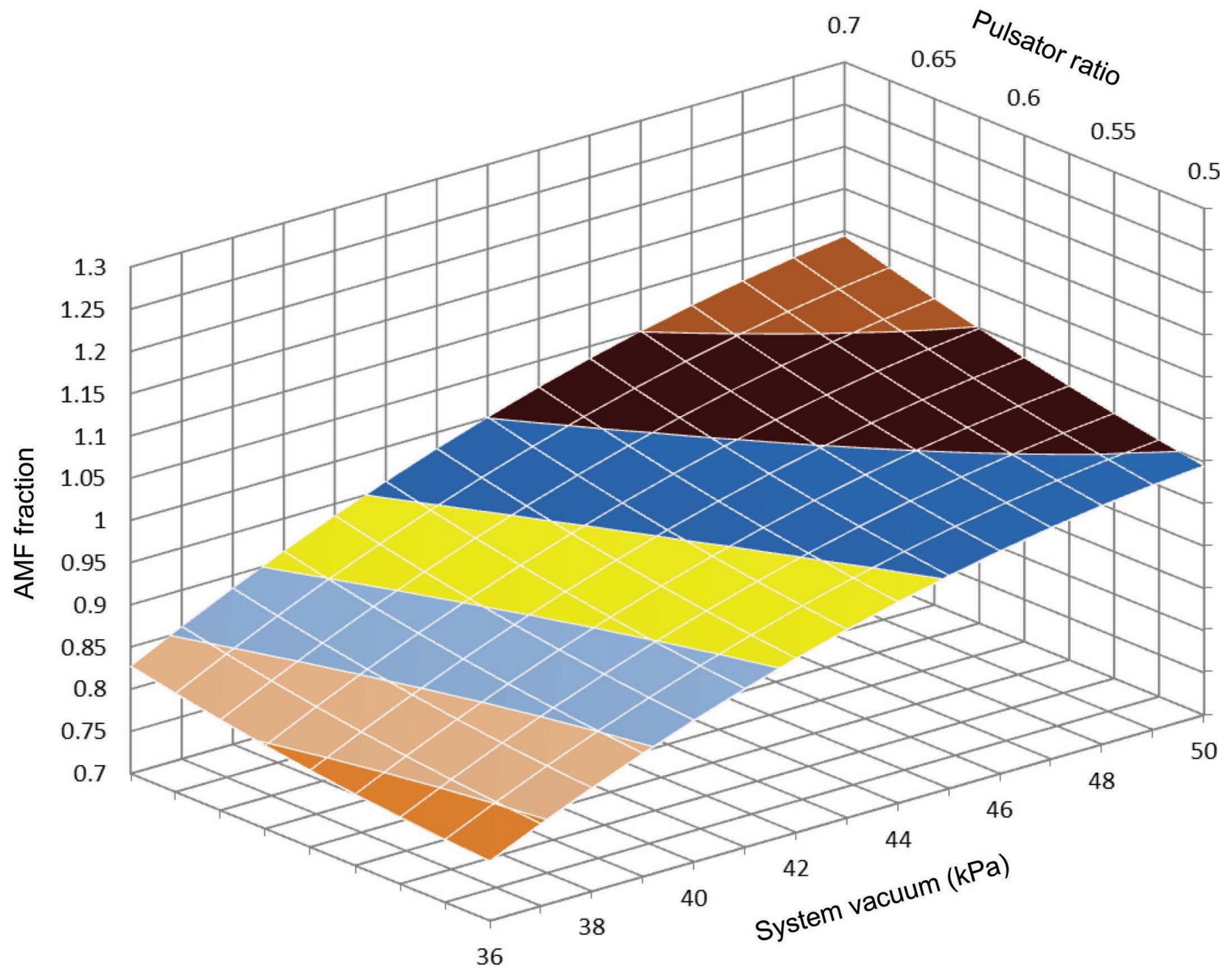

Figure 3. Average milk fraction flow response surface - Liner F. Average milk flow (AMF) is defined as a fraction around the average AMF relative to the within-cow mean for all treatments by system vacuum and pulsator ratio.

narrowest range of AMF across the 3 standard conditions. The difference in AMF between liners was small at the low and medium conditions. At the highest levels of $\mathrm{V}_{\text {system }}$ and $\mathrm{PR}$, particularly with the higher OP liners, milking staff reported more kicking and stepping during milking and increased color changes consistent with increased teat congestion observed after clusters were removed.

\section{DISCUSSION}

In this trial, we found small differences in $\mathrm{AMF}_{\mathrm{f}}$ between liners at the lowest $\mathrm{V}_{\text {system }}$ and $\mathrm{PR}$ conditions. This finding is likely because even the lowest OP liners could relieve the low level of teat-end congestion that developed under these milking conditions. The $\mathrm{AMF}_{\mathrm{f}}$ differences became more apparent as both $\mathrm{V}_{\text {system }}$

Table 5. Regression of claw vacuum versus milk flow rate during the peak flow period

\begin{tabular}{lccc}
\hline Item & No vent in liner & Mouthpiece vented & Short milk tube vented \\
\hline Regression coefficient $(\mathrm{kPa} / \mathrm{kg}$ per minute) & -0.65 & -1.34 & -1.57 \\
\hline
\end{tabular}


Table 6. Average milk flow $(\mathrm{kg} / \mathrm{min})$ response surface coefficients ${ }^{1}$

\begin{tabular}{|c|c|c|c|c|c|c|c|c|}
\hline Variable & \multicolumn{8}{|c|}{ Liner } \\
\hline $\begin{array}{l}\text { Intercept } \\
\mathrm{V}_{\text {claw }}{ }_{2} \\
\mathrm{~V}_{\text {claw }} \\
\mathrm{MR} \\
\mathrm{MR}^{2} \\
\mathrm{~V}_{\text {claw }} \times \mathrm{MR} \\
\text { Adjusted } \mathrm{R}^{2}\end{array}$ & $\begin{array}{l}-9.87 \\
2.66 \times 10^{-1} \\
-2.86 \times 10^{-3} \\
22.3 \\
-17.7 \\
\quad 2.24 \times 10^{-2} \\
\quad 0.817\end{array}$ & $\begin{array}{l}-26.7 \\
-5.60 \times 10^{-1} \\
-4.30 \times 10^{-3} \\
61.3 \\
-42.8 \\
-2.71 \times 10^{-1} \\
\quad 0.765\end{array}$ & $\begin{array}{l}-4.82 \\
9.46 \times 10^{-2} \\
-5.10 \times 10^{-4} \\
14.4 \\
-12.1 \\
-12.2 \\
\quad 0.967\end{array}$ & $\begin{array}{l}-0.657 \\
\quad 1.85 \times 10^{-1} \\
-1.11 \times 10^{-3} \\
-4.62 \\
\quad 7.43 \\
-4.99 \times 10^{-2} \\
\quad 0.909\end{array}$ & $\begin{array}{l}-22.6 \\
\quad 6.56 \times 10^{-1} \\
-6.54 \times 10^{-3} \\
42.1 \\
-29.3 \\
-1.73 \times 10^{-1} \\
\quad 0.942\end{array}$ & $\begin{array}{l}-11.4 \\
2.57 \times 10^{-1} \\
-1.92 \times 10^{-3} \\
26.6 \\
-19.3 \\
-5.60 \times 10^{-2} \\
\quad 0.904\end{array}$ & $\begin{array}{l}-8.99 \\
3.95 \times 10^{-1} \\
-4.71 \times 10^{-3} \\
11.3 \\
-9.38 \\
\quad 3.04 \times 10^{-2} \\
\quad 0.963\end{array}$ & $\begin{aligned} &-1.59 \\
& 1.71 \times 10^{-1} \\
&-2.98 \times 10^{-3} \\
& 2.53 \\
&-7.92 \\
& \quad 1.77 \times 10^{-1} \\
& \quad 0.681\end{aligned}$ \\
\hline
\end{tabular}

${ }^{1} \mathrm{~V}_{\text {claw }}=$ claw vacuum; $\mathrm{V}_{\text {claw }}{ }^{2}=$ claw vacuum squared; $\mathrm{MR}=$ milk ratio based on liner overpressure; $\mathrm{MR}^{2}=$ milk ratio squared; $\mathrm{V}_{\text {claw }} \times \mathrm{MR}=$ interactive term of claw vacuum and milk ratio.

and PR increased, indicating that increased OP (and LC) provided more congestive relief under these more extreme milking conditions. This finding is in agreement with observations made by Bade et al. (2009), who published response surfaces for a single liner type, with milking vacuum, b-phase duration, and LC being independently controlled. Our results showed a similar interaction between LC and both b-phase duration and milking vacuum with the effect of vacuum larger than the effect of b-phase duration.

The highest $\mathrm{AMF}_{\mathrm{f}}$ was observed at the highest levels of $\mathrm{V}_{\text {system }}, \mathrm{PR}$, and OP. However, it was apparent in this experiment based on milking staff observations, that cow comfort was compromised (as indicated by observed stepping and kicking before cluster removal) and teat tissues were more congested (as indicated by visual assessment of teat color and ringing). Mein et al. (2003) proposed that an OP of greater than 13 to $14 \mathrm{kPa}$ probably applies unnecessary and unproductive compression to many teat ends during the d phase and is likely to be associated with increased hyperkeratosis at the teat end.

Unlike the experiment described by Bade et al. (2009), LC within a selected liner type was not manipulated for a selected $V_{\text {system}}$. The liners selected for this study were chosen to approximate the range of OP for commercially available liners, from 0 to $18 \mathrm{kPa}$ (measured at pressure difference across the liner of 40 $\mathrm{kPa}$ ). This range of OP values was shown to correspond to LC values from 5 to $30 \mathrm{kPa}$ (Leonardi et al., 2015).

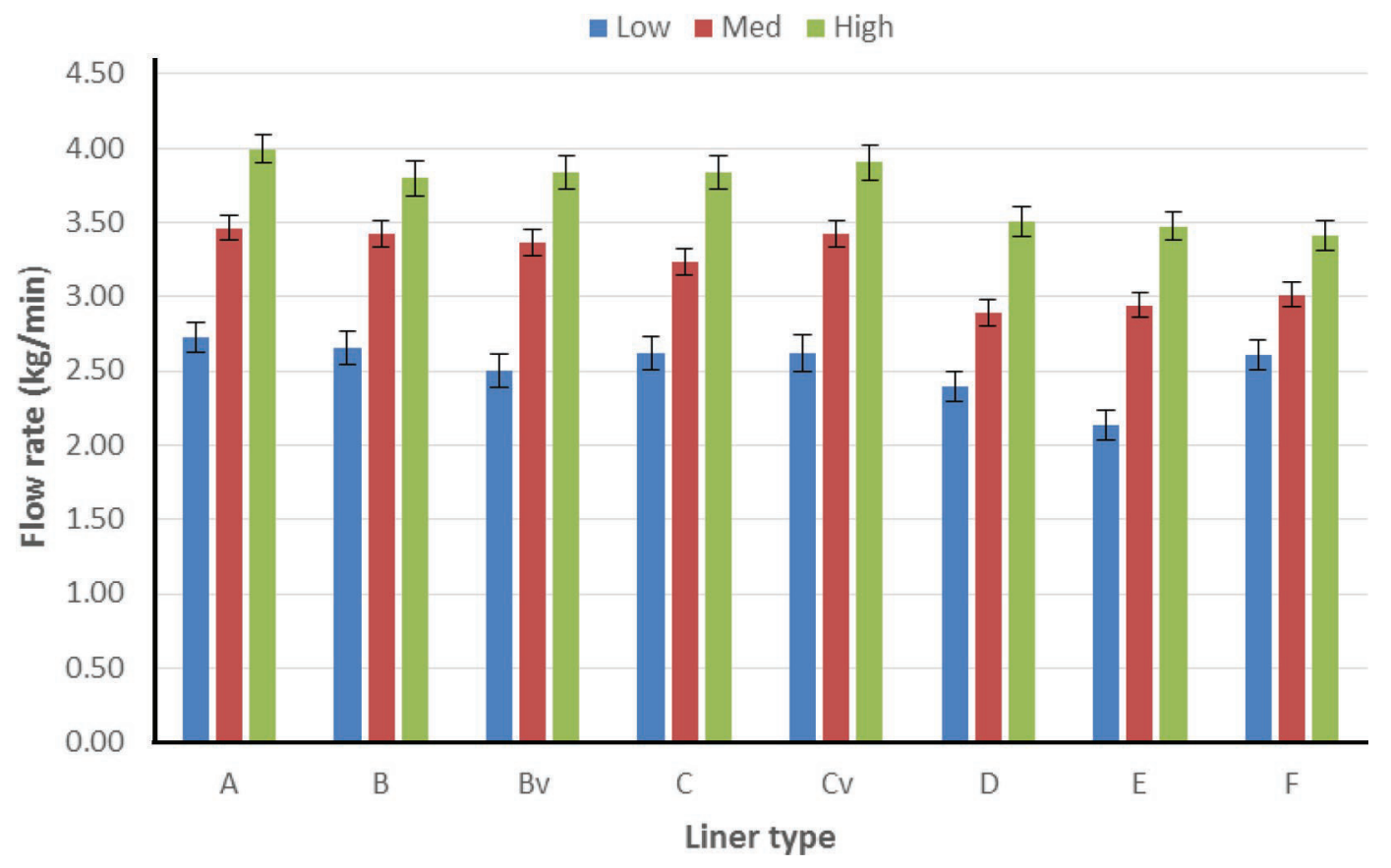

Figure 4. Average milk flow $(\mathrm{AMF})$ rate $(\mathrm{kg} / \mathrm{min})$ for low, medium, and high claw vacuum and milk ratio conditions. Low condition $=32$ $\mathrm{kPa}$ claw vacuum and 0.5 milk ratio; medium condition $=37 \mathrm{kPa}$ claw vacuum and 0.6 milk ratio; high condition $=42 \mathrm{kPa}$ claw vacuum and 0.7 milk ratio. Error bars signify SE estimates for all AMF estimates. 
For an individual liner, LC will increase by about $1 / 3$ of the increase in pressure difference across the liner wall (Bade et al., 2007; Mein and Reinemann, 2009; Reinemann, 2012).

Mein and Reinemann (2007) reported that the dominant effects of $\mathrm{V}_{\text {system }}$ and $\mathrm{PR}$ on milking speed occurred during the peak flow period and that milk flow rate during this period probably reaches a maximum level at a PR between 60:40 to 70:30 (Mein et al., 2004). Spencer et al. (2007) found that the interaction of $\mathrm{V}_{\text {system }}$ and PR was significant for both milk flow rate during the peak flow period and AMF when 2 silicon liners were assessed. In this experiment, using a constant d-phase duration across all treatments and calculating the MR for each liner was used to control for variability in milk flow rates introduced by differences in d-phase (which may contribute to changes in teat end congestion) and MR (which affects AMF) between liners and across treatment conditions. In previous studies the effects of differing MR and d-phase durations has been confounded with changes in other machine influences such as liner type and vacuum level (Thomas et al., 1993a; Spencer et al., 2007).

Our results are reported as $\mathrm{AMF}_{\mathrm{f}}$ to make them more applicable to predicting performance in parlor configurations and for herds with differing milking intervals, production levels, and premilking practices. $\mathrm{AMF}_{\mathrm{f}}$ response surfaces, or liner maps, allow for easy prediction of the changes in AMF for any farm-specific milking systems when $\mathrm{V}_{\text {system}}$, PR, or both are changed.

All test liners were attached to vented claws. Test liners without any liner vents (A, B, C, D) had a vacuum drop between the claw and milk line of $0.6 \mathrm{kPa} / \mathrm{kg}$ per minute. An increase in vacuum drop between claw and milk line to $1.3 \mathrm{kPa} / \mathrm{kg}$ per minute was seen when $\mathrm{MP}$ vents were added to claw venting (liner $\mathrm{E}$ ). The largest vacuum drop $(1.6 \mathrm{kPa} / \mathrm{kg}$ per minute) occurred for liners with SMT vents in addition to claw vents (liners $\mathrm{Bv}, \mathrm{Cv}, \mathrm{F})$. These results indicate the effect of liner venting on $\mathrm{V}_{\text {claw }}$ levels and that MP venting produced less vacuum drop than SMT venting, presumably due to less air admission averaged over the pulsation cycle.

Liner venting had a clear effect of lowering $\mathrm{V}_{\text {claw }}$, and liner OP had a clear effect on MR - decreasing liner OP increases MR as milk flows during a greater percentage of the a and c phases of pulsation; both of these can affect AMF. These effects were accounted for with estimations made in $\mathrm{V}_{\text {claw }}$ and MR specific to each liner-treatment combination to facilitate comparisons between liners under similar milking conditions. This study is the first time we are aware of liner performance being compared at the same level of $\mathrm{V}_{\text {claw }}$ and $\mathrm{MR}$.

The second objective of this study was to evaluate a methodology for assessing liner performance that can be applied on commercial dairy farms. Previous studies have reported aspects of liner performance using data collected from commercial parlors: Bade et al. (2009), Rasmussen and Madsen (2000), and Spencer et al. (2007). The standardized condition methodology used in this study can be applied in the field by taking simple measurements to determine the relationship between $\mathrm{V}_{\text {system }}$ and $\mathrm{V}_{\text {claw }}$, and by measuring liner OP to determine the relationship between $\mathrm{PR}$ and MR to adjust milking speed measurements derived from milk meters to the same milking conditions. These corrections allow a more objective comparison of the differences due to the liner itself.

This experiment illustrates several other methods to improve the design of field trials of milking performance. The CCD, as also used by Bade et al. (2009), can be applied in the field using repeated $\mathrm{CPt}$ treatments to detect and account for changes in milking characteristics and herd characteristics over time. Some stall-to-stall variability will be introduced by differences in the accuracy of commercial milk meters calibration. Rotation of clusters to different milking stalls, when more than one cluster per liner type is used simultaneously, will detect and account for this source of variability. Randomization of treatments T1 to T8 within each complete CCD cycle and repeating the CPt every third treatment is considered important for this design as is completing at least 2 experimental cycles. When automatic cluster removers are used in the parlor, AMF data should be carefully scrutinized for inconsistencies due to manual or kicked off detachment. These data should be removed from any subsequent analysis. Finally, it is important to note that signs of cow discomfort and teat congestion occurred at high levels of $\mathrm{V}_{\text {system }}$ and $\mathrm{PR}$ in this study, although this information was based on milking staff observation and not through a systematic visual assessment method. In addition to assessing milking speed in field studies, it is also important to assess cow behavior and teat tissue responses, which can vary between teats under the same milking system settings. These evaluations can be done by a systematic visual assessment of cow stepping and kicking during the low flow period, teat skin color change, ringing at the base of the teat, and teat tissue firmness as described by Reinemann (2012).

\section{CONCLUSIONS}

The highest $\mathrm{AMF}_{\mathrm{f}}$ was observed at the highest levels of $\mathrm{V}_{\text {system }}, \mathrm{PR}$, and OP. Furthermore, the range of $\mathrm{AMF}_{\mathrm{f}}$ over the vacuum and pulsation settings investigated was influenced by liner OP. All liners showed an increase in AMF as standardized conditions of $\mathrm{V}_{\text {claw }}$ and MR progressed from low to high. The inclusion and 
position of a liner venting system affect $\mathrm{V}_{\text {claw }}$ relative to $V_{\text {system }}$. Where AMF is assessed against $V_{\text {claw }}$ rather than $\mathrm{V}_{\text {system }}$, any venting system within the liner can be accounted for. The accuracy of liner performance assessment in commercial parlors fitted with milk meters can be improved by using CCD with repeated $\mathrm{CPt}$ experimental design, rotating different clusters to different stalls or milk meters, and adjusting performance estimates for similar $\mathrm{V}_{\text {claw }}$ and $\mathrm{MR}$ conditions.

\section{ACKNOWLEDGMENTS}

Milk harvesting research conducted at the University of Wisconsin-Madison is supported by Avon Dairy Solutions (Melksham, UK), Dairy Australia (Melbourne), and Teagasc (Fermoy, Ireland).

\section{REFERENCES}

Bade, R. D., D. J. Reinemann, and G. A. Mein. 2007. Sources of variability in compressive load applied to bovine teats. Pages 212-213 in 46th Natl. Mastitis Counc. Ann. Mtg. Proc., San Antonio, TX. Natl. Mastitis Counc. Inc., Madison, WI.

Bade, R. D., D. J. Reinemann, M. Zucali, P. L. Ruegg, and P. D. Thompson. 2009. Interactions of vacuum, b-phase duration, and liner compression on milk flow rates in dairy cows. J. Dairy Sci. 92:913-921.

Box, G. E. P., and K. B. Wilson. 1951. On the experimental attainment of optimum conditions. J. Royal Stat. Soc. B 13:1-38.

Clough, P. A. 1972. Pipeline milking machines and milking systems. Agric. Eng. 27:17-24.

Gomez, S. A., D. J. Reinemann, and P. D. Thompson. 2011. Predicting liner performance. Pages 121-122 in 50th Natl. Mastitis Counc. Ann. Mtg. Proc., Arlington, VA. Natl. Mastitis Counc. Inc., Madison, WI.

Hamann, J., G. A. Mein, and S. Wetzel. 1993. Teat tissue reactions to milking: effects of vacuum level. J. Dairy Sci. 76:1040-1046.

Hillerton, J. E. 2005. Do liners differ? Pages 133-138 in 44th Natl. Mastitis Counc. Ann. Mtg. Proc., Orlando, FL. Natl. Mastitis Counc. Inc., Madison, WI.

International Organisation for Standardization (ISO). 2007a. ISO 3918: Milking machine installations-Vocabulary. ISO, Geneva, Switzerland.

International Organisation for Standardization (ISO). 2007b. ISO 5707: Milking machine installations-Construction and performance. ISO, Geneva, Switzerland.

Leonardi, S., J. F. Penry, F. M. Tangorra, P. D. Thompson, and D. J. Reinemann. 2015. Methods of estimating liner compression. J. Dairy Sci. 98:6905-6912.

Mein, G. A., and D. J. Reinemann. 2007. Making the most of machine on time: What happens when the cups are on? Pages 18-30 in 46th
Natl. Mastitis Counc. Ann. Mtg. Proc., San Antonio, TX. Natl. Mastitis Counc. Inc., Madison, WI.

Mein, G. A., and D. J. Reinemann. 2009. Biomechanics of milking: Teat-liner interactions. Pages 1-15 in Am. Soc. Agric. Biol. Eng. Ann. Int. Mtg. Proc., Reno, Nevada. Am. Soc. Agric. Biol. Eng., St. Joseph, MI.

Mein, G. A., D. J. Reinemann, I. Ohnstad, and E. J. O‘Callaghan. 2004. 100 years with liners and pulsators: Where the rubber meets the teat and what happens to milking characteristics. Bull. Int. Dairy Fed. 388:28-34.

Mein, G. A., D. M. Williams, and C. C. Thiel. 1987. Compressive load applied by the teatcup liner to the bovine teat. J. Dairy Res. 54:327-337.

Mein, G. A., M. D. Williams, and D. J. Reinemann. 2003. Effects of milking on teat-end hyperkeratosis: 1 . Mechanical forces applied by the teatcup liner and responses of the teat. Pages 114-123 in 42nd Natl. Mastitis Counc. Ann. Mtg. Proc., Ft. Worth, TX. Natl. Mastitis Counc. Inc., Madison, WI.

Rasmussen, M. D., and N. P. Madsen. 2000. Effects of milkline vacuum, pulsator airline vacuum, and cluster weight on milk yield, teat condition, and udder health. J. Dairy Sci. 83:77-84.

Reinemann, D. J. 2012. The smart position on teat condition. Pages 124-131 in Proc. of the New Zealand Milk Quality Conference, Hamilton, New Zealand. Dairy New Zealand, Hamilton, New Zealand.

Reinemann, D. J., and G. A. Mein. 2010. Review of milking biomechanics research. Pages 436-443 in Proc. Int. Dairy Fed. Mastitis Conf., Christchurch, NZ. Int. Dairy Fed., Brussels, Belgium.

Reinemann, D. J., P. D. Thompson, and I. Ohnstadt. 2013. Exploring the role of liner shape, dimensions and venting on liner performance. Pages 64-70 in 52nd Natl. Mastitis Counc. Ann. Mtg. Proc., San Diego, CA. Natl. Mastitis Counc. Inc., Madison, WI.

Schukken, Y. H., L. G. Petersson, and B. J. Rauch. 2006. Liner and teat health. Pages 183-196 in 45th Natl. Mastitis Counc. Ann. Mtg. Proc., Tampa, FL. Natl. Mastitis Counc. Inc., Madison, WI

Spencer, S. B., and G. W. Rogers. 2004. Optimization of milking machine liners. Pages 507-514 in 100 Years with Liners and Pulsators in Machine Milking. IDF Bull. No. 388. Int. Dairy Fed., Brussels, Belgium.

Spencer, S. B., J. W. Shin, G. W. Rogers, and J. B. Cooper. 2007. Short communication: Effect of vacuum and ratio on the performance of a monoblock silicone milking liner. J. Dairy Sci. 90:17251728.

Thomas, C. V., D. R. Bray, and M. A. Delorenzo. 1993a. Evaluation of $50 / 50$ and $70 / 30$ pulsation ratios in a large commercial dairy herd. J. Dairy Sci. 76:1298-1304.

Thomas, C. V., M. A. Delorenzo, and D. R. Bray. 1993b. Prediction of individual cow milking time for milking parlor simulation models. J. Dairy Sci. 76:2184-2194.

Williams, D. M., G. A. Mein, and M. R. Brown. 1981. Biological responses of the bovine teat to milking: Information from measurements of milk flow-rate within single pulsation cycles. J. Dairy Res. 48:7-21.

Zucali, M. R. D., A. Tamburini, and R. Bade. 2008. Effects of liner compression on teat end hyperkeratosis. Pages $2-5$ in Am. Soc. Agric. Biol. Eng. Ann. Int. Mtg. Proc., Providence, RI. Am. Soc. Agric. and Biol. Eng., St Joseph, MI. 